\title{
Research on Station Position and Transfer Mode of Qingdao Metro Liuting Airport Station
}

\author{
WANG Xiao ${ }^{1, a}$, ZHANG Meng ${ }^{2, b}$ \\ ${ }^{1}$ Qingdao Binhai University, China \\ ${ }^{2}$ China Railway Engineering Consulting Group Co., Ltd., China \\ awangxiao_tj@163.com, b zhangmengcq@163.com
}

\begin{abstract}
Keywords: Qingdao metro; Station position; Transfer mode
Abstract: With the development of our social economy and the advancement of urbanization, China's urban traffic demand continues to grow rapidly, more and more cities are affected by the traffic jam. In order to solve the urban traffic problem fundamentally, many cities are embarking on the construction of rail transit. With the encryption of the urban rail transit network, the design problem of the transfer station is becoming more and more important to the designers. The Liuting airport station needs to reserve the forward transfer node and connect with the large public transport system, and its design is typical. How to deal with the influence of the transfer relationship, the construction sequence and the surrounding environment of the large passenger flow station is the key problem in this station. This project cases have certain reference significance for similar projects.
\end{abstract}

\section{Project overview}

Qingdao metro line 1 has a total length of $59.941 \mathrm{~km}$, all of which are underground, and the line rises from Huangdao, and passes through the main city of Qingdao and ends at Dongguozhuang of Chengyang. There are 39 stations, all of which are underground stations, including 12 transfer stations. Qingdao metro line 1 is the north-south backbone line for the connection of Huangdao district, the central district of Qingdao city and Chengyang district, connecting some important transportation junction, such as the railway station, the north railway station, the liuting international airport, Huangdao bus station, the north bus station and so on. It is transferred to 11 lines, forming a line network interconnection and resource sharing. It is also the only rail transit link between Huangdao and central urban areas in the recent line network.

\section{Research on Liuting airport station program}

\section{Station overview}

\section{Station position}

Liuting airport station is the 34th station of Qingdao metro line 1. The station is located in the east of the airport parking lot, and the southeast of the intersection of Xinzheng Road and Minhang Road. It is arranged in the north-South and transferred to the forward line 10.

Underground pipelines

There are less pipelines laid out in Xinzheng Road, mainly for street lamps, water supply and optical fiber. The location of stations is mainly for green space planning, and the main body and the subsidiary part are not affected by pipelines.

\section{Traffic condition}

Xinzheng Road: On the south side of the intersection, the road is two-way six-lane, the total width of which is $24 \mathrm{~m}$. The road on the north side is two-way four-lane and the total width is $14 \mathrm{~m}$. The traffic volume of Xinzheng Road is large, both sides are mainly the office buildings related to the airport, and the planning is basically realized.

Minhang Road: The road is two-way four-lane and the total width is $14 \mathrm{~m}$. The traffic volume is 
large, and the planning is basically realized.

The construction of ground and underground

The southwest of Xinzheng Road and Minhang Road intersection is the international terminal parking lot, with a basement and underground parking lot for pile foundation, the depth of which is $15 \mathrm{~m}$, its south side is the domestic terminal parking lot. The airport terminal is located in the west side of the parking lot. The southeast of the intersection is the landscape of small hills, lush trees, and its south side is the airport fire pool. From the east to the west, the northeast of the intersection is the airport office, the East Airlines comprehensive building; and the northwest is the Civil Aviation Administration of Qingdao, the airport police station, border office etc...

\section{Land planning}

The transportation and land planning near the airport has been basically realized, and the surrounding planning is mainly green space, public transportation, commercial and administrative office. According to the planning of the development research of Qingdao Airport Economic Zone, Qingdao Liuting International Airport will be relocated in recent years, and the old site will be changed into commercial land.

\section{Analysis of environmental characteristics}

(1)According to the planning data, after the relocation of the airport, the terminal building may be changed into commercial, with a larger passenger flow. The north side is a relatively concentrated area of office land, and the passenger flow is equally large. The selection of station position should also take into account the future passenger flow of the airport and the north of Minhang Road.

(2)The front and rear of the station is affected by airport terminal, underground parking lot and nearby buildings, and the line position is relatively limited, especially in the north end, which is set with curves.

(3)Minhang Road and Xinzheng Road are the main roads to enter and exit the airport, with large traffic and heavy volume. So in order to avoid traffic impact, during subway construction, traffic can not be blocked or lanes can not be reduced. On both sides of the road, the buildings are dense and the roads do not have the conditions for traffic guidance and reform.

(4)The airport parking space is tense, so the station implementation should avoid the big impact on the airport parking lot.

(5)In the north side, the buildings are dense, and the scale is large, and the conditions of the land use are tense.

(6)During the construction period, the airport parking lot will operate as usual with the one-way, and the surface traffic should make an overall planning, keep the original traffic flow line at the entrance and exit of the parking lot and minimize the impact of the ground traffic.

(7)According to geological survey, the southeast of the intersection is covered the landscape of small hills, lush trees. If the station is set here, the vegetation should be moved in time according to seasonal orders, and the hill is put slope according to the construction requirements and the enclosure range.

(8)The forward line 10 is attributable to long term planning and line requirements, which can only be laid along Minhang Road.

\section{Selection of station position}

The selection of subway station position need to fully take into account the recent passenger flow and long-term commercial passenger flow. Xinzheng Road and Minhang Road is the main road around Liuting airport station. On both sides of Minhang Road and the north side of Xinzheng Road, the density of commercial buildings and office buildings is high, so from the airport parking lot to the north of Minhang Road, and southeast of the intersection which has good implementation conditions should be required to study. According to the division of station service scope, we can get two positions: airport domestic terminal parking lot program, Minhang Road and Xinzheng Road intersection program. Two station positions are compared as follows. 
Table 1 Station position comparison

\begin{tabular}{|c|c|c|}
\hline Program & $\begin{array}{l}\text { Airport domestic terminal parking lot } \\
\text { program }\end{array}$ & $\begin{array}{c}\text { Minhang Road and Xinzheng Road intersection } \\
\text { program }\end{array}$ \\
\hline $\begin{array}{l}\text { Program } \\
\text { description }\end{array}$ & $\begin{array}{l}\text { The station is located under the airport } \\
\text { domestic terminal parking lot. The forward } \\
\text { line } 10 \text { is set up east-west along the Minhang } \\
\text { Road, in the east of the intersection of } \\
\text { Minhang Road and Xinzheng Road. }\end{array}$ & $\begin{array}{l}\text { The station is located in the southeast of the } \\
\text { intersection, the east side of the airport parking } \\
\text { lot, with the north-south direction. The forward } \\
\text { Line } 10 \text { station is set up east-west along the } \\
\text { Minhang Road, basically intersected with line } \\
\text { 1. }\end{array}$ \\
\hline $\begin{array}{l}\text { General } \\
\text { layout }\end{array}$ & 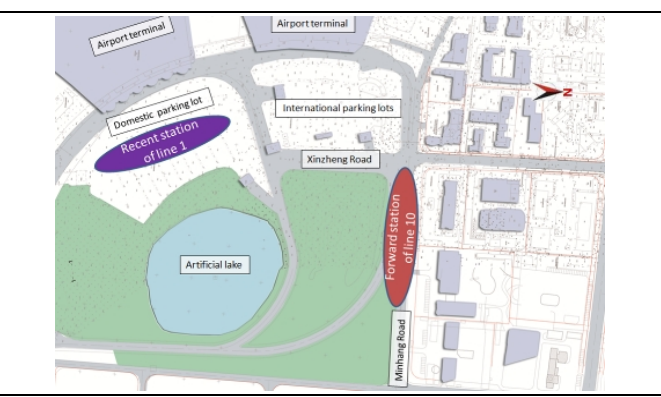 & 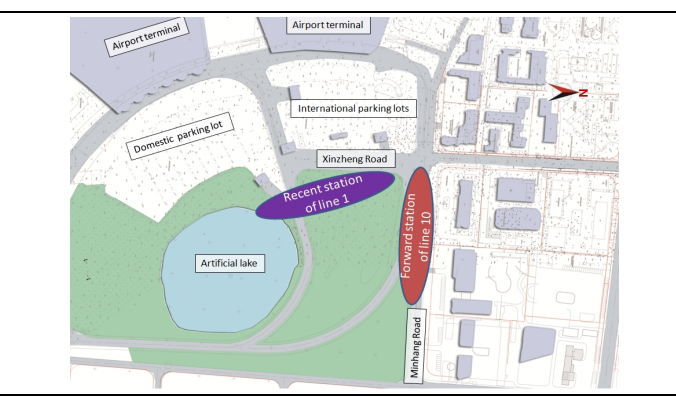 \\
\hline $\begin{array}{l}\text { Passenger } \\
\text { flow } \\
\text { attraction } \\
\text { capacity }\end{array}$ & $\begin{array}{l}\text { The station can attract the recent passenger } \\
\text { flow and long-term commercial passenger } \\
\text { flow of the airport, but it's less attractive to the } \\
\text { passenger flow of Xinzheng Road. }\end{array}$ & $\begin{array}{l}\text { The station can attract the passenger flow } \\
\text { around Xinzheng Road, and take into account } \\
\text { the recent passenger flow of the airport. The } \\
\text { station needs to reserve the entrance and exit of } \\
\text { the airport terminal during construction, so as } \\
\text { to attract the airport forward business traffic. }\end{array}$ \\
\hline Transfer & $\begin{array}{l}\text { It is far away from the forward line } 10 \text {, and the } \\
\text { transfer is inconvenient. }\end{array}$ & $\begin{array}{l}\text { Cross, } T \text { type, } L \text { type and other transfer modes } \\
\text { can be realized with the station of the forward } \\
\text { Line } 10 \text {. The transfer is more convenient. }\end{array}$ \\
\hline $\begin{array}{c}\text { Site } \\
\text { conditions }\end{array}$ & $\begin{array}{l}\text { Parking Spaces are tense and the condition is } \\
\text { poor. }\end{array}$ & $\begin{array}{l}\text { The station is mainly located in the landscape } \\
\text { hill and the green area of parking lot. The site } \\
\text { conditions are very good. }\end{array}$ \\
\hline $\begin{array}{l}\text { The ground } \\
\text { traffic } \\
\text { organization }\end{array}$ & No need & $\begin{array}{l}\text { During the construction period, only the road at } \\
\text { the entrance of the parking lot will be removed. }\end{array}$ \\
\hline $\begin{array}{l}\text { Impact on } \\
\text { parking lots }\end{array}$ & $\begin{array}{l}\text { It has great influence on the operation of } \\
\text { domestic and international parking lots. }\end{array}$ & $\begin{array}{l}\text { Only partial of the entrance of the domestic } \\
\text { parking lot needs to be adjusted. }\end{array}$ \\
\hline $\begin{array}{l}\text { Comprehensi } \\
\text { ve evaluation }\end{array}$ & Poor & Good \\
\hline
\end{tabular}

According to the previous analysis, although airport domestic terminal parking lot program can attract the recent passenger flow and long-term commercial passenger flow of the airport, but the program has great impact on the airport operation, and the site conditions are tense, the implementation is poor, and the station position is far away from the forward line 10, and the transfer is inconvenient. Therefore, Minhang Road and Xinzheng Road intersection program is more reasonable and the comprehensive evaluation is better. Then we can do further research on the intersection program.

\section{Selection of station design scheme}

Through the research and analysis, three schemes of the intersection program are selected to do further research. 
Scheme 1: The recent station of line 1 is set at the landscape hill and the green area of parking lot at southeast of the intersection, the forward station is set at the east side of the intersection, transfer by double channel.

Scheme 2: The recent station of line 1 astride the intersection of Minhang Road and Xinzheng Road, the forward station is set at the east side of the intersection, transfer by $\mathrm{T}$ node.

Scheme 3: The recent station of line 1 is set at the landscape hill and the green area of parking lot at southeast of the intersection, the forward station is set at the west side of the intersection, transfer by $\mathrm{T}$ node.

The implementation of Scheme 3 will break the pile on the approach viaduct from the intersection to the terminal, so its implementation is poor. Therefore, further comparison is made between scheme 1 and scheme 2(see table 2).

\begin{tabular}{|c|c|c|c|}
\hline \multicolumn{2}{|c|}{ Content } & Scheme 1 & Scheme 2 \\
\hline \multicolumn{2}{|c|}{$\begin{array}{l}\text { Station position and scheme } \\
\text { description }\end{array}$} & $\begin{array}{l}\text { The recent station is set up under the } \\
\text { landscape hil at southeast of the } \\
\text { intersection, transfer by double } \\
\text { channel. The station of line } 1 \text { is an } \\
\text { underground two-level island station, } \\
\text { which is set up on the top. The station } \\
\text { ofline } 10 \text { is an underground three-level } \\
\text { island station, which is set up on the } \\
\text { below. The transfer node is reserved for } \\
\text { the forward station by the recent } \\
\text { station. }\end{array}$ & $\begin{array}{l}\text { The recent station astride the intersection, } \\
\text { the forward station is set at the east side of } \\
\text { the intersection, transfer by } T \text { node. The } \\
\text { station of line } 1 \text { is an underground two-level } \\
\text { island station, which is set up on the top. } \\
\text { The station of line } 10 \text { is an underground } \\
\text { three-level island station., which is setup on } \\
\text { the below. The transfer node is reserved for } \\
\text { the forward station by the recent station. }\end{array}$ \\
\hline \multicolumn{4}{|c|}{ General layout } \\
\hline \multicolumn{2}{|c|}{ Station Style } & $\begin{array}{l}\text { The recent station is a double-layer } \\
\text { three span rectangular structure, the } \\
\text { platform widh is } 13 \mathrm{~m} \text {, the forward } \\
\text { station is three-layer three span } \\
\text { rectangular structure, the platform } \\
\text { width is } 13 \mathrm{~m} \text {. }\end{array}$ & $\begin{array}{l}\text { The recent station is a double-layer three } \\
\text { span rectangular structure, the platform } \\
\text { width is } 13 \mathrm{~m} \text {, transfer nodes are three-layer } \\
\text { three span rectangular structures. The } \\
\text { forward station is three-layer three span } \\
\text { rectangular structure, the platform width is } \\
13 \mathrm{~m} \text {. }\end{array}$ \\
\hline \multicolumn{2}{|c|}{ Transfer mode } & Double channel transfer & T node transfer \\
\hline \multicolumn{2}{|c|}{ Construction method } & Open-Cut construction, less risk & Open-Cut construction, less risk \\
\hline \multirow[b]{2}{*}{ Analysis } & Advantage & $\begin{array}{l}\text { (1)The transfer mode is well matched } \\
\text { with the characteristics of passenger } \\
\text { flow, and the transfer ability is large. } \\
\text { (2)The station reservation project is } \\
\text { small, and only the transfer channel } \\
\text { interface need to be reserved. } \\
\text { (3)The road and parking lot are not } \\
\text { required during the construction period. }\end{array}$ & $\begin{array}{l}\text { (1)The station has a good attraction of } \\
\text { passenger flow. } \\
\text { (2)The transfer is convenient, with the short } \\
\text { transfer distance and the transfer function is } \\
\text { better. }\end{array}$ \\
\hline & Disadvantage & $\begin{array}{l}\text { (1)The forward station is three layers } \\
\text { and the vohume of the construction is } \\
\text { slightly larger. } \\
\text { (2)This scheme can not fully take into } \\
\text { account the passenger flow of the north } \\
\text { side of Minhang Road. } \\
\text { (3)The transfer is smooth, but the } \\
\text { distance is longer. }\end{array}$ & $\begin{array}{l}\text { (1)The transfer passenger flow is } \\
\text { concentratad at one side of the station, and } \\
\text { the transfer is organized by the station hall } \\
\text { (2)For the recent station, the amount of } \\
\text { projectreservation is slightly larger. } \\
\text { (3)The forward station is three layers and } \\
\text { the volume is slightly larger. } \\
\text { (4)The station platform is required to } \\
\text { reserve the transfer node, and it will affect } \\
\text { the layout of the recent station, and the } \\
\text { design is more complex. } \\
\text { (5)During the construction period, Minhang } \\
\text { Road and Xincheng Road will be occupied, } \\
\text { and the traffic and parking lot can be } \\
\text { affected, and the implementation is poor. }\end{array}$ \\
\hline
\end{tabular}

In summary, although scheme 1 can not fully take into account the passenger flow of the north side of Minhang Road, the transfer distance is long, but the construction does not occupy the road and parking lot, the implementation is good, and taking into account the Line 10 for long-term planning 
line, there are some uncertainties, this scheme can avoid long-term quantities, the design of the forward station will be more flexible, so scheme 1 has comprehensive advantages. Scheme 2 has better attraction of passenger flow, and better transfer function with line 10. However, during the construction period, Minhang Road and Xinzheng Road will be occupied, and the traffic and parking lot can be affected, and its implementation is poor. In a comprehensive comparison, scheme 1 has an obvious advantage. Therefore, scheme 1 is taken as a recommendation plan.

\section{Conclusions}

Urban rail transit is a highly comprehensive and complicated huge system engineering, its construction should be considered various factors such as city planning, transport interchange, landscape building, residents of commercial traffic distribution, the construction cost and so on, and should coordinate and comprehensive analysis of the factors to get optimal solution.

(1)Urban planning is the guide. The station will be built mainly for the service of the airport passenger flow. According to the planning data, the airport will be relocated, the airport terminal is subject to new functional adjustment and more likely to be commercialized. Therefore, the choice of station position needs to take account of the recent airport operation and long-term business functions.

(2)The transfer scheme should be flexible when the forward station line is unstable. According to the forward line network planning, the station position of line 10 can only be laid down along Minhang Road, but the station position is unstable. Therefore, it is recommended to use channel transfer mode, which is more flexible.

(3)Give priority to use function. In the design of the station, we should take full account of the characteristics of the existing passenger flow of the airport and the future commercial passenger flow. As the transfer capacity of channel transfer mode is large, it is well matched with the passenger flow characteristics.

(4)The implementation conditions are the main determination of the program. The traffic at the intersection of Minhang Road and Xinzheng road is busy, there are lots of buildings in the north of the intersection, the parking lot is very intense. These restrictive factors determine the layout of the scheme.

\section{References}

[1] GB50157-2013,Code for design of metro.

[2] LI Pu, KANG Yue-hua, WU Zi-han. Transfer Mode Design for Yanghuyuan Station on Changsha Rail Transit Line 3. RAILWAY STANDARD DESIGN,2014,58(03):97-100.

[3] Chong Zhi-guo. Research on Beijing Metro Hujialou transfer station program. RAILWAY STANDARD DESIGN,2014,58(10):105-108.

[4] Li Wenqian. Impact of Rail Transit Construction on Commercial Spatial Distribution in Beijing. Urban Rapid Rail Transit,2008,21(06):19-22.

[5] Li Min. Architectural Design of Zhongshan Road Transfer Station of Nanchang Metro Line 1 and Line 3. Underground Engineering and Tunnels,2010(02):18-21+68. 